\title{
Relationship Between Behavioural Traits and Performance Test Scores in Sport Horses
}

\author{
L. KRŠKOVÁ ${ }^{1}$, J. MLYNEK ${ }^{2}$, M. HALO ${ }^{2}$ \\ ${ }^{1}$ Comenius University, Faculty of Natural Science,
} Department of Animal Physiology and Ethology, Bratislava, Slovakia ${ }^{2}$ Slovak University of Agriculture, Department of Animal Husbandry, Nitra, Slovakia

\author{
Received July 15, 2002
}

Accepted March 25, 2003

\begin{abstract}
Kršková L., J. Mlynek, M. Halo: Relationship Between Behavioural Traits and Performance Test Scores in Sport Horses. Acta Vet. Brno 2003, 72: 429-435.

The objective of this work was to demonstrate the relationship between performance test scores and the individual differences in behaviour of sport horses. Individual differences in emotionality expressed by behavioural traits (conditioned by the type of nervous system) were determined as differences of spontaneous reactions (exploratory behaviour) to new and unknown environment of a testing arena $(4.5 \times 6$-meter room divided into 12 squares $-3 \times 4$ configuration). Using a modified open-field test (habituation test), we observed 14 Slovak sport pony breed horses. Individual differences in emotionality expressed by behaviour and summarized in the frequencies of locomotor activity were used as criteria for classification of the horses into categories as follows: low emotionality (the horses crossed less than 130 squares during 40 minutes $-57.14 \%$ of the tested animals), medium emotionality (the horses crossed from 131 to 220 squares $-7.14 \%$ of the tested animals) and high emotionality (the horses crossed more than 220 squares during 40 minutes $37.71 \%$ of the tested animals). Individual horses with a low level of emotionality achieved a higher score in the performance test than the animals with high emotionality.

Slovak sport pony, behaviours, open-field test, performance test
\end{abstract}

Training is an important part of the preparation of sport horses for a performance test. From the physiological point of view, training is mainly an adaptation process, which poses increased demands on mental processes of sport horses. Early determination of differences in excitability of the central nervous system enables an individual approach to training (Hanák 1983). A typological distribution is possible on the basis of the frequency of exploratory activities occurring per time unit, as well as on the speed of habituation (Lát 1967, 1973). Habituation is defined as a decrement of an innate response as a result of repetitive stimulation (Hernández - Peón 1960). It is classified as the most simple kind of learning: learning not to respond to neutral environmental stimuli. Information on the learning abilities of horses should be used in developing training methods (McCall 1990).

Based on the above-mentioned knowledge, we decided to verify the use of open-field (habituation) test methods of horses. Individual horses with a low level of emotionality as expressed by behavioural traits were included in group E (stands for "elite" as given by horse performance test scale, STN 466310 - Slovak Technical Norm 4663 10) for the performance test. Based on the evaluation by trainer, these horses had a very good performance score and very good results in a 100-day test (Medvecký et al. 1992; Halo 1992; Kršková 2000a). These horses seemed to be more suitable and safe for children horse-riding courses (Kršková and Halo 1998; Kršková 2000b).

Performance of horses, whether in sports or leisure, depends on both physical abilities as well as temperament. Visser et al. (2001) proved that behavioural tests may be used

Address for correspondence:

RNDr. Lucia Kršková, PhD.

Comenius University, Faculty of Natural Science

Department of Animal Physiology and Ethology,
Phone: + 421260296680

Fax: + 421265429064
E-mail: krskova@fns.uniba.sk

http://www.vfu.cz/acta-vet/actavet.htm 
to reliably identify individual behaviour variables and temperament traits in young horses. The purpose of this study was to document the relationship between the categorization of horses on the basis of the differences in emotionality and performance test scores.

\section{Materials and Methods}

We observed 14 Slovak sport pony breed horses ( 6 mares, 7 stallions, 1 gelding - Table 1$)$. Animals were housed in a stable situated $50 \mathrm{~m}$ away from the testing chamber. The distance between the testing chamber and the stable guaranteed isolation of the tested animals. All horses had passed a 100-day test a (100-day training finished with the performance test), and the performance test (overall review of the evaluated signs, features and testing disciplines).

The Slovak sport pony was chosen especially for the needs of riding a horse course of older children (8-16-yearold). It is a crossbreed of domestic warm-blooded mares, with their typical smaller growth, and Welsh pony stallions of section "B" (the height at withers does not exceed $137.2 \mathrm{~cm}$ ).

Table 1

Data of the tested animals

\begin{tabular}{|l|c|c|c|c|c|}
\hline Name & Sex & Date of birth & Date of experiment & Mother/father & Time of experiment \\
\hline IBER & stallion & 12.2 .1990 & 30.1 .1996 & Búrka/Luskáãik & $09: 33 \mathrm{~h}$ \\
\hline JOURA & mare & 1.1 .1991 & 16.1 .1996 & Fistula/Fain & $10: 39 \mathrm{~h}$ \\
\hline JASNÁ & mare & 20.1 .1991 & 15.1 .1996 & Carmen/Fain & $09: 33 \mathrm{~h}$ \\
\hline JACHTA & mare & 25.1 .1991 & 30.11 .1995 & Aida/Fain & $11: 33 \mathrm{~h}$ \\
\hline JARABINA & mare & 27.1 .1991 & 16.1 .1996 & Búrka/Fain & $09: 35 \mathrm{~h}$ \\
\hline JAGA & mare & 15.3 .1991 & 15.1 .1996 & Fortuna/Fain & $10: 24 \mathrm{~h}$ \\
\hline JAWA & mare & 26.4 .1991 & 16.1 .1996 & Drahofiica/Fain & $11: 25 \mathrm{~h}$ \\
\hline KASÍNO & gelding & 5.1 .1992 & 30.1 .1996 & Aida/Fain & $10: 30 \mathrm{~h}$ \\
\hline KAPITÁN & stallion & 7.1 .1992 & 28.5 .1996 & Carmen/Fain & $09: 23 \mathrm{~h}$ \\
\hline LESK & stallion & 27.2 .1993 & 15.5 .1996 & Aida/Fain & $11: 31 \mathrm{~h}$ \\
\hline LIBOR & stallion & 9.4 .1993 & 15.5 .1996 & Fistula/Fain & $10: 37 \mathrm{~h}$ \\
\hline LOTOS & stallion & 4.6 .1993 & 28.5 .1996 & Fanka/Grant & $10: 20 \mathrm{~h}$ \\
\hline MOHYKÁN & stallion & 21.3 .1994 & 29.5 .1996 & Hviezda/Dukát & $10: 55 \mathrm{~h}$ \\
\hline MOTEL & stallion & 1.4 .1994 & 29.5 .1996 & Dukát/Chrupka & $10: 07 \mathrm{~h}$ \\
\hline
\end{tabular}

The experiments took place in the testing (habituation) chamber built for this purpose at the facility of the Slovak University of Agriculture in Količany. The chamber, with a floor size of $4.5 \times 6 \mathrm{~m}$ and a height of $2.5 \mathrm{~m}$, was divided into 12 squares of $1.5 \times 1.5 \mathrm{~m}$ each, with a $3 \times 4$ configuration. It was also equipped with a oneway window. An observer was in a side-room and observed the horses through a one-way window. The frequency of observed activities were recorded on a notepad.

We used the modified open field (habituation) test for horses (Medvecký et al. 1992). Our observations took place between 09.00 and $12.00 \mathrm{~h}$. Each tested horse was placed in the testing chamber by an assistant. The following activities were recorded each minute within the 40-minute observation period: frequency of locomotor activity (transition of squares - grid-crossing), standing, vocalization (snorting and neighing), defecation and urination, sniffing, as well as other behaviours (pawing, head swinging, turning, activity towards the chamber entrance, activity towards the one-way window). The ethological characteristics of the individual animals was determined on the basis of their individual behaviours. Emotionality is expressed by the summary figures of the frequency of indicators, while habituation is reflected in the dynamics of the course of response intensity. Based on the emotionality values measured during the experiment, the animals were divided into three categories: low, medium, and high emotionality. For practical purposes, the activities for statistics processing were reduced to just locomotor activity, which is the most significant demonstration of behaviour in unknown environment (Medvecký et al. 1992). Based on our data, the tested animals were divided into groups as follows: low the horses crossed less than 130 squares during $40 \mathrm{~min}$ ), medium (the horses crossed from 131 to 220 squares) and high (the horses crossed over 220 squares) emotionality.

The tested horses were classified to groups on the basis of individual differences in behaviour. Their results were compared with those obtained in the 100-day test (which together with the physiological test forms the preliminary performance test) and with the main performance test score (STN 466310 - Slovak Technical Norm 4663 10). 
Statistical analysis

Non-parametric, double-preferential Mann-Whitney $U$-test and Spearman rank correlation were used.

\section{Results}

On the basis of the observations, the following results have achieved:

The open field test showed that the process of habituation (decrease in the frequency of observed activities) occurred in most horses within the first 20-30 min. In four animals ( $\mathrm{n}=$ 14), the process of dishabituation occurred (increase in the frequency of observed activities) in the last $10 \mathrm{~min}$ of the period.

The more frequent activity in an unknown territory was the locomotor activity (gridcrossing). Other activities were the only additional information about individual emotional characteristics.

On the basis of the frequency of grid-crossing (locomotor activity), the tested animals were divided into three groups (Table 2) - the majority of the tested horses ( 8 from a total of 14 horses $=57.14 \%$ of those tested) were low-emotionality horses, there was only one medium-emotionality horse $(7.14 \%$ of the tested individuals), and the group of highemotionality individuals was represented by 5 tested horses $(37.71 \%$ from total of 14 tested individuals). The correctness of the categorisation was verified statistically using MannWhitney $U$ test (Table 3 ) with the following results:

between the group of high and low-emotionality individuals there were significant differences $(P<0.05)$ in the number of crossed squares - locomotor activity,

the other activities seemed to be supplementary - illustrating the running process of habituation,

using the Spearman rank correlation (Table 4), a positive correlation was found between the activity of pawing and the activity towards the chamber entrance $(P<0.05$, $\mathrm{R}=0.581)$, negative correlation occurred between the activity of turning and locomotor activity $(P<0.05, \mathrm{R}=-0.603)$ and between defecation and turning $(P<$ $0.05, \mathrm{R}=-0.560)$.

Table 2:

Frequency of locomotor activity $(\mathrm{n}=14)$

\begin{tabular}{|c|c|c|c|c|c|}
\hline \multicolumn{2}{|c|}{$\begin{array}{l}\text { Low-emotionality } \\
\text { horses }\end{array}$} & \multicolumn{2}{|c|}{$\begin{array}{c}\text { Medium -emotionality } \\
\text { horses }\end{array}$} & \multicolumn{2}{|c|}{$\begin{array}{c}\text { High -emotionality } \\
\text { Horses }\end{array}$} \\
\hline$\underset{\Sigma}{z}$ & 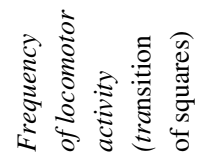 & 气ั & 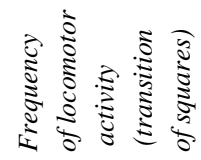 & $\underset{\Xi}{z}$ & 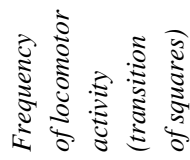 \\
\hline IBER & 31 & JOURA & 131 & LOTOS & 231 \\
\hline JASNÁ & 37 & & & KASÍNO & 258 \\
\hline JAGA & 52 & & & JARABINA & 299 \\
\hline KAPITÁN & 69 & & & MOHYKÁN & 307 \\
\hline LESK & 76 & & & JAWA & 472 \\
\hline MOTEL & 95 & & & & \\
\hline LIBOR & 101 & & & & \\
\hline JACHTA & 113 & & & & \\
\hline Average & 71.75 & & & & 313.40 \\
\hline
\end{tabular}


Table 3:

Statistical differences between the group of high- $(\mathrm{n}=5)$ and low- $(\mathrm{n}=8)$ emotionality horses (Mann-Whitney $U$-test)

\begin{tabular}{|c|c|}
\hline Indicators & $\begin{array}{c}\text { Differences between the group of high- }(\mathrm{n}=5) \\
\text { and low-emotionality (n=8) horses }\end{array}$ \\
\hline Locomotor activity (grid-crossing) & $0.004+$ \\
\hline Vocalization (snorting and neighing) & 0.608 \\
\hline Sniffing & 1.000 \\
\hline Defecation & 0.456 \\
\hline activity towards the one-way window & 0.659 \\
\hline activity towards the chamber entrance & 1.000 \\
\hline Pawing with forelimb & 0.179 \\
\hline Head swinging & 0.836 \\
\hline Turning & 0.363 \\
\hline
\end{tabular}

Legend: $+P<0.05 \quad++P<0.01 \quad+++P<0.001$

Table 4:

The stability of behavioural indicators $(n=14)$ - Spearman rank correlation

\begin{tabular}{|c|c|c|c|c|c|c|c|c|c|}
\hline & & $\begin{array}{c}\text { activity } \\
\text { towards the } \\
\text { one-way } \\
\text { window }\end{array}$ & $\begin{array}{r}\text { activity } \\
\text { towards th } \\
\text { chamber } \\
\text { entrance }\end{array}$ & defecation & Turning & $\begin{array}{c}\text { Head } \\
\text { swin- } \\
\text { ging }\end{array}$ & $\begin{array}{c}\text { Pawing } \\
\text { with } \\
\text { forelimb }\end{array}$ & $\begin{array}{c}\text { vocalisa- } \\
\text { tions }\end{array}$ & sniffing \\
\hline \multirow{2}{*}{$\begin{array}{l}\text { locomotor } \\
\text { activity }\end{array}$} & $\mathrm{R}$ & 0,181 & 0,307 & 0,344 & $-0,603$ & $-0,299$ & 0,485 & 0,070 & $-0,015$ \\
\hline & $\mathrm{P}$ & 0,514 & 0,268 & 0,215 & $0,029+$ & 0,28 & 0,080 & 0,799 & 0,955 \\
\hline \multirow[t]{2}{*}{ Sniffing } & $\mathrm{R}$ & 0,306 & 0,024 & 0,021 & 0,015 & $-0,315$ & $-0,066$ & 0,669 & \\
\hline & $\mathrm{P}$ & 0,271 & 0,929 & 0,939 & 0,957 & 0,256 & 0,811 & 0,118 & \\
\hline \multirow{2}{*}{$\begin{array}{l}\text { Vocaliza- } \\
\text { tions }\end{array}$} & $\mathrm{R}$ & 0,034 & $-0,478$ & $-0,344$ & 0,354 & 0,139 & 0,215 & & \\
\hline & $\mathrm{P}$ & 0,902 & 0,084 & 0,215 & 0,201 & 0,617 & 0,439 & & \\
\hline \multirow{2}{*}{$\begin{array}{l}\text { Pawing } \\
\text { with } \\
\text { forelimb }\end{array}$} & $\mathrm{R}$ & 0,581 & 0,071 & 0,34 & $-0,338$ & 0,276 & & & \\
\hline & $\mathrm{P}$ & $0,036+$ & 0,799 & 0,219 & 0,223 & 0,319 & & & \\
\hline \multirow{2}{*}{$\begin{array}{l}\text { Head } \\
\text { swinging }\end{array}$} & $\mathrm{R}$ & 0,017 & 0,002 & $-0,110$ & 0,308 & & & & \\
\hline & $\mathrm{P}$ & 0,952 & 0,993 & 0,691 & 0,267 & & & & \\
\hline \multirow[t]{2}{*}{ Turning } & $\mathrm{R}$ & $-0,5814$ & $-0,351$ & $-0,560$ & & & & & \\
\hline & $\mathrm{P}$ & 0,124 & 0,206 & $0,044+$ & & & & & \\
\hline \multirow[t]{2}{*}{ Defecation } & $\mathrm{R}$ & 0,471 & 0,407 & & & & & & \\
\hline & $\mathrm{P}$ & 0,089 & 0,142 & & & & & & \\
\hline \multirow{2}{*}{$\begin{array}{l}\text { Activity } \\
\text { towards } \\
\text { the chamber } \\
\text { entrance }\end{array}$} & $\mathrm{R}$ & 0,38 & & & & & & & \\
\hline & \begin{tabular}{|l|}
$\mathrm{P}$ \\
\end{tabular} & 0,170 & & & & & & & \\
\hline
\end{tabular}

Legend: $\mathrm{R}-$ Spearman rank correlation

$+P<0.05 \quad++P<0.01 \quad+++P<0.001$

Dividing the animals into groups on the basis of locomotor activity was compared with the results achieved in the 100-day test and the results in the main performance test (Table 5). In the 100-day test the low-emotionality horses achieved an average point evaluation (8.9 point) higher than the individuals of the high-emotionality animals group (7.9 point). Within the group of horses of low-emotionality there were $50 \%$ of the horses ranked among the elite 
according to the main performance test score (E, score: $8.1-9.0$ points) and $50 \%$ in the $1^{\text {st }}$ class (I, score: 7.1-8.0). In horses of high emotionality only $20 \%$ of the animals ranked among the elite. The remaining $80 \%$ ranked among the $1^{\text {st }}$ class. In the group of animals of medium emotionality there is only one animal, which received 9.5 points in 100 -day test and ranked among the $1^{\text {st }}$ class on the base of its performance score. However, the existence of statistically significant differences (Mann-Whitney $U$-test) in the 100-day test has not been confirmed between the representatives of the group with low and high emotional horses $(P<$ $0.05, \mathrm{P}=0.184)$.

Table 5

Relation between categorization (on the basis of emotionality) and training load ( $\mathrm{n}=14$ )

\begin{tabular}{|c|c|c|c|c|c|c|c|c|}
\hline \multirow[b]{2}{*}{ Name } & \multicolumn{2}{|c|}{$\begin{array}{l}\text { Horses with low } \\
\text { Emotionality }\end{array}$} & \multicolumn{3}{|c|}{$\begin{array}{l}\text { Horses with medium } \\
\text { Emotionality }\end{array}$} & \multicolumn{3}{|c|}{$\begin{array}{l}\text { Horses with high } \\
\text { emotionality }\end{array}$} \\
\hline & $\begin{array}{c}\text { 100-day } \\
\text { test } \\
\text { score }\end{array}$ & $\begin{array}{c}\text { Main } \\
\text { perfor- } \\
\text { mance } \\
\text { test (class) }\end{array}$ & Name & $\begin{array}{c}\text { 100-day } \\
\text { test } \\
\text { score }\end{array}$ & $\begin{array}{c}\text { Main } \\
\text { perfor- } \\
\text { mance } \\
\text { test (class) }\end{array}$ & Name & $\begin{array}{c}\text { 100-day } \\
\text { test } \\
\text { score }\end{array}$ & $\begin{array}{c}\text { Main } \\
\text { perfor- } \\
\text { mance } \\
\text { test (class) }\end{array}$ \\
\hline IBER & 10 & $\mathrm{E}$ & & & & LOTOS & 7.3 & I. \\
\hline JASNÁ & 7 & I. & JOURA & 9.5 & I. & KASÍNO & 8 & $E$ \\
\hline JAGA & 10 & I. & & & & JARABINA & 9.5 & I. \\
\hline KAPITÁN & 9 & I. & & & & MOHYKÁN & 7.1 & I. \\
\hline LESK & 7.5 & I. & & & & JAWA & 7.5 & I. \\
\hline MOTEL & 8.5 & $E$ & & & & & & \\
\hline LIBOR & 9.5 & $E$ & & & & & & \\
\hline JACHTA & 10 & $\mathrm{E}$ & & & & & & \\
\hline Average & 8.9 & & & & & & 7.9 & \\
\hline
\end{tabular}

Final classification on the basis of performance test score

(Slovak technical norm 4663 10): E - elite (score: 8.1-9.0), I. - $1^{\text {st }}$ class (score: 7.1-8.0)

\section{Discussion}

Our results provide information about emotionality and the speed of habituation in horses. We found that the process of habituation occurred in the majority of animals within the first 20-30 min. The 40-minute time interval, as well as the period of testing, seemed to be satisfactory. In four horses $(n=14)$ the process of dishabituation occurred in the last 10 minutes of the period, and it was manifested by an increase in their locomotor activity.

According to Czako and Novacký (1985), dishabituation occurs when some other stimulus is given in the course of the habituation procedure and thus affects (interrupts) the habituation process. In our study, such stimulus could have been the sounds coming from the outside surroundings.

The level of emotionality was determined on the basis of locomotor activity frequency (criteria of distribution). Vocalisations, defecation and urination, sniffing of the floor, door, windows, pawing, head swinging, turning, flehmen, etc. were the only additional information about individual emotional characteristics.

We included urination in the experiment despite the assumption that it would not be as frequent in horses as, e.g., in pigs. Ihle (1984) claims that urination is significantly related to daytime, level of working load, individual year seasons and climatic factors, and no other factors affect the course of the analysed manifestation. However, in our experiment, no animal urinated. In our opinion, to the fact, that the horses in this activity needed a peaceful and familiar environment. 
The existence of individual differences between testing animals was demonstrated not only in speed of the habituation process, but also in the preference of a specific activity. Horses with a low frequency of locomotor activity were usually swinging their heads intensively or pawing with forelimbs.

On the basis of the emotionality represented with the frequency of the locomotor activity, the tested individuals were divided into groups of high-, medium- and low-emotionality animals. In the group of low-emotionality horses the majority $(57.14 \%)$ of the tested animals was included. This was a satisfactory result. The Slovak sport pony has been popular especially for children horse-riding courses. The low-emotionality animals did not manifest any behavioural sings of excitement in an unknown environment. Because of safety reasons, they are more suitable for work with children than horses belonging to medium- and highemotionality groups.

No significant differences in the 100-day test were found between the low- and highemotionality groups.

\section{Vzt’ah medzi excitabilitou športových koní a výsledkymi v skúškach výkonnosti}

Cielom našej práce bolo dokázat existenciu vztahu medzi výsledkami skúšok výkonnosti športových koní a excitabilitou. Individuálne rozdiely v excitabilite sú podmienené rozdielmi $\mathrm{v}$ spontánnych aktivitách (exploračnom správaní) v novom neznámom prostredí predstavovanom testovacou komorou (miestnostou s rozmermi $5 \times 6$ metrov, rozdelenou na 12 štvorcov $-3 \times 4$ štvorce). Za využitia modifikovaného open-field testu (habituačného testu) sme sledovali 14 koní úžitkového typu Slovenský športový pony. Individuálne rozdiely $\mathrm{v}$ excitabilite vyjadrené frekvenciou motorickej aktivity sú kritériom rozdelenia zvierat do skupiny nízko (kone prešli menej ako 130 štvorcov za 40 min. - 57.14\% nami testovaných zvierat), stredne (kone prešli od 131 do 220 štvorcov $7.14 \%$ nami testovaných zvierat) a vysoko excitabilných zvierat (kone prešli viac ako 220 štvorcov za 40 minút $-37.71 \%$ testovaných zvierat). Kone s nízkou hladinou excitability dosahovali v skúškach výkonnosti vyššie bodové hodnotenie ako zvieratá s vyššou excitabilitou.

\section{References}

CZAKO, M, NOVACKÝ, M 1985: Porovnávacia psychológia. Bratislava, SPN. 255 p.

HALO, M 1992: Biologické a výkonnostné vlastnosti $\mathrm{F}_{1}, \mathrm{~F}_{11}, \mathrm{~F}_{2}$ a $\mathrm{F}_{10}$ generácie malých športových koní. Thesis, Slovak Agricultural University, Nitra. 110 p.

HANÁK, J 1983: Fyziologie tréningu sportovních a dostihových koní.(In Czech), Praha: TURF KLUB. 149 p.

HERNÁNDEZ-PEÓN, R 1960: Neurophysiological correlates of habituation and other manifestations of plastic inhibition. Electroencephal. clin. Neurophysiology, Suppl. 13: 101-114.

IHLE, P 1984: Ethologische studie ber den Tagesrhytmus von Pferden in Abhngigkeit von der Haltunngsform. Dissertation, Giessen. 204 p.

KRŠKOVÁ, L, HALO, M 1998: The selection criteria in the breeding of Slovak sport pony. In: Book of Abstracts of the 49th Annual Meeting of The European Association for Animal Production. Warsaw. p. 298

KRŠKOVÁ, L 2000a: Využitie sledovania excitability CNS z hladiska adaptácie športových koní na tréningovú zátaž. In: „Chov koní v novom tisícročí““. Nitra. pp. 59-60

KRŠKOVÁ, L 2000b: Orientačno pátracie správanie slovenského športového pony v novom prostredí. In: Správy Slovenskej zoologickej spoločnosti, 18. p. 55-60

LÁT, J 1967: K výkladu fenoménu extrikce/habituace/ a spontánní obnovy. In: Čs fysiol 16: 237-238

LÁT, J 1973: The analysis in habituation. In: Acta Neurobiol 33: 771-789

McCALL, CA 1990: A review of learning behavior in horses and its application in horse training. J Anim Sci 68: $75-81$

MEDVECKÝ, D, HALO, M, NOVACKÝ, M 1992: Porovnávanie habituačného testu s výkonnostou a využitelnostou koní. In: XIX. Interdisciplinární etologická konference. Lísek u Bystřice nad Perštejnem, Skalský Dvůr. p. 80.

STN 4663 10. Plemenné kone. 1998. 
VISSER, EK, Van REENEN, CG, HOPSTER, H, SCHILDER, MBH, KNAAP, JH, BARNEVELD, A, BLOKHUIS, HJ 2001: Quantifying aspects of young horses' temperament: consistency of behavioural variables. Appl Anim Behav Sci 74: 241-258 